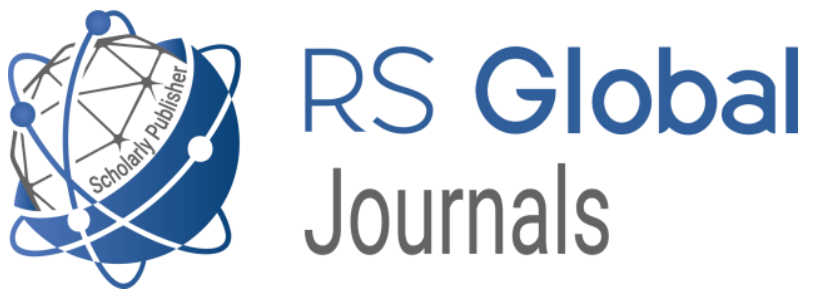

Scholarly Publisher

RS Global Sp. z O.O.

ISNI: 0000000484952390

Dolna 17, Warsaw, Poland 00-773

Tel: +48226022703

Email: editorial_office@rsglobal.pl

JOURNAL International Journal of Innovative Technologies in Social Science

p-ISSN 2544-9338

e-ISSN 2544-9435

PUBLISHER RS Global Sp. z O.O., Poland

\begin{tabular}{|c|c|}
\hline ARTICLE TITLE & $\begin{array}{l}\text { DENOMINATIONS AND FOREIGN MISSIONS IN THE } \\
\text { KARAK REGION DURING THE PERIOD OF OTTOMAN } \\
\text { ORGANIZATIONS } 1864-1918 \text { A.D. }\end{array}$ \\
\hline AUTHOR(S) & $\begin{array}{l}\text { Hadi Abdel Fattah Al-Mahasneh, Al Masoud Ashraf Thamer, } \\
\text { Hashem Mansur Alhashem }\end{array}$ \\
\hline ARTICLE INFO & $\begin{array}{l}\text { Hadi Abdel Fattah Al-Mahasneh, Al Masoud Ashraf Thamer, } \\
\text { Hashem Mansur Alhashem. (2021) Education in Schools of } \\
\text { Christian Denominations and Foreign Missions in the Karak } \\
\text { Region During the Period of Ottoman Organizations } 1864-1918 \\
\text { A.D. International Journal of Innovative Technologies in Social } \\
\text { Science. 3(31). doi: } 10.31435 / \text { rsglobal_ijitss/30092021/7640 }\end{array}$ \\
\hline DOI & https://doi.org/10.31435/rsglobal_ijitss/30092021/7640 \\
\hline RECEIVED & 17 May 2021 \\
\hline ACCEPTED & 10 July 2021 \\
\hline PUBLISHED & 16 July 2021 \\
\hline LICENSE & $\begin{array}{l}\text { (c) } \underset{\text { (i) }}{ } \\
\text { This work is licensed under a Creative Commons Attribution } \\
\text { 4.0 International License. }\end{array}$ \\
\hline
\end{tabular}

(C) The author(s) 2021. This publication is an open access article. 


\title{
EDUCATION IN SCHOOLS OF CHRISTIAN DENOMINATIONS AND FOREIGN MISSIONS IN THE KARAK REGION DURING THE PERIOD OF OTTOMAN ORGANIZATIONS 1864-1918 A.D.
}

\author{
Dr. Hadi Abdel Fattah Al-Mahasneh, Aqaba University of Technology, Jordan \\ Dr. Al Masoud Ashraf Thamer, Emirate of Al-Jawf Region, KSA \\ Dr. Hashem Mansur Alhashem, Jordanian custom, Jordan
}

DOI: https://doi.org/10.31435/rsglobal_ijitss/30092021/7640

\section{ARTICLE INFO \\ Received 17 May 2021 \\ Accepted 10 July 2021 \\ Published 16 July 20212021 \\ KEYWORDS \\ Education, schools, Christian denominations, missionary missions, Ottoman organizations, concessions, nationals of the state, the Ottoman Empire.}

\begin{abstract}
Attention to education in the schools of Christian denominations and foreign missionary missions formed the basis for the modern renaissance in eastern Jordan, and Ottoman reforms in the second half of the nineteenth century AD contributed to advancing education among members of the Christian denominations who were subjects of the Ottoman Empire in eastern Jordan to be They have their own educational institutions under their supervision and management. The system of Ottoman privileges allowed foreign countries to build educational institutions and spread missionary missions throughout the Ottoman Empire, including Karak.
\end{abstract}

Citation: Hadi Abdel Fattah Al-Mahasneh, Al Masoud Ashraf Thamer, Hashem Mansur Alhashem. (2021) Education in Schools of Christian Denominations and Foreign Missions in the Karak Region During the Period of Ottoman Organizations 1864-1918 A.D. International Journal of Innovative Technologies in Social Science. 3(31). doi: 10.31435/rsglobal_ijitss/30092021/7640

Copyright: (C) 2021 Hadi Abdel Fattah Al-Mahasneh, Al Masoud Ashraf Thamer, Hashem Mansur Alhashem. This is an open-access article distributed under the terms of the Creative Commons Attribution License (CC BY). The use, distribution or reproduction in other forums is permitted, provided the original author(s) or licensor are credited and that the original publication in this journal is cited, in accordance with accepted academic practice. No use, distribution or reproduction is permitted which does not comply with these terms.

Ottoman reforms and their impact on the establishment of schools for Christian denominations.

Like the people of other non-Muslim sects in all Ottoman states, Christians enjoyed in Karak, in their own sectarian organization, autonomy in their sectarian system, which was in place in the Ottoman Empire. To allow the Dhimmis to maintain their own laws and apply those laws to the people of the same religion under the supervision of a recognized spiritual authority that is responsible to the government [1].

The Ottoman Empire also affirmed, in its reformist decrees issued in the period of the organizations, the principle of equal treatment of its citizens of different religions and sects; The articles of those decrees, especially the charitable organization's decree issued on 11 Jumada al-Akhira in $1272 \mathrm{AH} / 17$ February 1856AD, dealt with the rights of religious minorities, and approved all previous concessions granted to them, and affirmed the principle of freedom of religions and sects and the conduct of their rites, and the right to build churches, monasteries, schools and hospitals Sectarian eligibility, restoration of existing ones, and occupation of government jobs according to the competence of persons, not of their religious, sectarian, or ethnic affiliation, and the right to sue nonMuslim individuals in front of their spiritual superiors [2].

Ottoman reforms contributed to advancing education, especially among members of the Christian sects. The Milla system gave non-Muslims among the subjects of the Ottoman Empire to have their own institutions under the management and supervision of their spiritual leaders, and the 
system of privileges allowed foreign countries to build educational institutions and spread missionary missionaries in Throughout the Ottoman Empire [2].

As for the Ottoman legislation in the field of educational reform, the charitable organizations decree issued on 11 Jumada al-Akhera on 1272 AH / 8 February 1856 CE stipulated that citizens of the Ottoman state be accepted without discrimination in civil and military schools, as long as they are subject to the prescribed conditions stipulated in the instructions of government schools, from As for age and passing required exams, the decree also stipulated the right of non-Muslim sects and minorities to establish their own educational institutions [2].

However, these reforms did not amount to the European countries that sought to implement the proposed reforms, as mentioned in the French protest memorandum dated 14 Shawwal $1283 \mathrm{AH} / 22$ February 1867AD. The intermediate level which Christians accept in some regions of the country [3].

Establishment of schools for Christian denominations in Karak.

Reform efforts and the European influence have resulted in the issuance of the regulations for public knowledge issued on 24 Jumada al-Awwal 1286 AH / 1 September 1869 CE, in which Article Hundred and Twenty-nine of them stipulated the conditions for granting licenses for the establishment of private schools, whether by the state's knowledge administration and the state governor or from Dar Al Saada (Istanbul) by the Department of Knowledge (Ministry) [3].

By looking at one of the licensing forms granted to the Latin Patriarchate in Jerusalem to open a male school for the Latins in the city of Karak and the information included in it, we find that the system was accurate in terms of determining the authority requesting the license, the duration of study at the school, the name of the institution or body supervising it and its responsible director, And the books taught in the school, the method of controlling the exams and teaching, and the necessity of informing the Department of Knowledge (Ministry) of any changes or additions to the license conditions granted to the Latin Patriarchate, where the instructions stipulated that no book should be taught outside the authorized books, and it is necessary to obtain On ratification when replacing a book with another, with the necessity of reviewing and providing the necessary information if the school needs to be moved from one place to another, notifying acquaintances or government employees to attend student exams and reward distribution parties, and providing a list of the names of students who have a school certificate, who will graduate and the need to provide a schedule Students are permanent, and provide the necessary facilities for knowledge inspectors during their visit to school with the necessity of a strict adherence by the founders and teachers to the provisions of Article (129) of the Public Knowledge System that was written on the back of the license [4].

\section{1- Greek Orthodox schools.}

Among the schools of the Christian denominations that were established in Karak during the period of the Ottoman organizations, the Greek Orthodox School, which was founded in 1288 AH / $1870 \mathrm{CE}$, which is one of the oldest sectarian schools according to the documents that can be found, including what was mentioned by the English traveler, Tristram, who visited the region between my two years 1288-1290 AH / 1870-1872 AD, where he indicated in his memoirs the existence of the school [4], and that the English traveler Dowling mentioned the existence of this school when he visited the city of Karak in $1314 \mathrm{AH} / 1896 \mathrm{AD}$, and the number of its students was estimated at (120) students [5] And the priest of Jerusalem, the priest, Nicola Khoury (1302-1373 AH / 1885-1954 AD), states that he learned in this school when his father was transferred He worked as a priest in the city of Karak in the year $1317 \mathrm{AH} / 1899 \mathrm{AD}$, where he mentioned in his memoirs that he enrolled in the school and he was Umrah at that time (14) years, where he found that the school was a carefully organized organization, and he realized in this school the value of science and education and carefully received by the teacher Kostandi Salah from Ram God, who paid attention to him in appreciation of his father, and received private lessons on his hands to be able to enter the seminary in Jerusalem [5], and he also received the seriousness and attention from the school administration and teachers what he compensated for his school days in Birzeit School, which indicates that the period of study in it was useless. Thanks to this school and its teachers he was able to continue his education at the seminary in Jerusalem. Perhaps what he mentioned is a reference to his preference for education in Karak over what was practiced in Birzeit, in which he spent the first years of his life, as it is clear from this indication that there were advanced classes in the school beyond the primary level, and from reading the history of his enrollment in the seminary in Jerusalem at the age of sixteen One year, it is clear that he spent two years in Karak School [7]. 
Nicola Khoury's notes are not limited to providing information about the Greek Orthodox school when he was a student, but rather he provides information of some importance when he was appointed a priest in Karak and practiced education in the same school where he learned in the year $1323 \mathrm{AH} / 1905 \mathrm{AD}$, where he was appointed as a second teacher, and the teacher was The first is the principal of the school, Tohma El Khoury from Salt, and the Turkish language teacher Hanna AlAmmarin from Karak, as well as the third teacher for the young Grace Jerus of Karak also [6]. Append their children to it and $\mathrm{k}$ The school has grown to a level that exceeds the level of the government school, which means the Rashidiya School, which was founded in the city of Karak in 1317 AH / 1899 $\mathrm{AD}$, after the primary school that was established in $1311 \mathrm{AH} / 1893 \mathrm{AD}$ was upgraded, and this indicates the primacy of the establishment of denominational schools in Karak over the establishment of government schools and the extent of care Made by spiritual chiefs of priests and clergy [6].

As for the subjects that were taught in school, Mitri Zureikat states in his diaries that he learned in them and that the subjects he studied are: Christian religious sciences, reading, writing, arithmetic, geography, history, and the arts [6], just as the Turkish language was taught there, As is evident from Nicholas Khoury's diary of appointing a Turkish teacher, Hanna Al-Ammarin [7], and from the teachers who worked in this school; Ya'qub Khoury, Salama bin Issa al-Qusus, Khalil bin alKhury Ibrahim, Khalil bin Sulaiman al-Qusus [15], and Khalil Khoury [7].

\section{2- Romanian Orthodox girls' schools.}

As for the school of Roman Orthodox girls in Karak, the earliest reference to it is contained in the memoirs of the English traveler Dowling when he visited the city of Karak in 1314 AH / 1896 CE, where he indicated the existence of this school and estimated the number of its students by about (60) students [8], as well That priest Nicola Khoury mentioned in his memoirs that in the year $1323 \mathrm{AH} /$ $1905 \mathrm{CE}$, he found that the school was late and needed attention and care, and that he made an effort to upgrade it to the level of the male school previously mentioned [9], and the Sectarian Church notebook indicates that most of the teachers Those who were studying in the school are girls from the community in the city of Karak, and this gives a strong indication of Ensha Education among the Greek Orthodox in the city of Karak [8]. The Orthodox Patriarchate in Jerusalem allowed some teachers to teach in the school when the need arises, and among the teachers who studied there was Nicola Khoury, the teacher in the school of the male community [8].

\section{3- Latin schools in Karak.}

Education in the city of Karak was not limited to the Greek Orthodox sect, but it also saw an activity in this field with the Latin community, which clearly shows the extent of competition between the sects in the establishment of schools, as Naim Hassan mentioned during his visit to the Horan and Karak provinces by saying: ((And that these sects are racing to open schools as if they were In the field of the cruiser)) [9], and the document establishing the Latin School in Karak showed that the sect obtained an official license from the Ministry of Public Knowledge's glasses in Istanbul to establish a school for boys in the city of Karak in 1293 AH / 1875 CE [8], where the document indicates The licensing authority is the Latin Patriarchate of Jerusalem, and the director is responsible for School is Anton Khoury Abed Rabbo, and teaching level where the primary daytime males came in a document license that the glasses (Ministry) knowledge to allow the teaching of the following subjects in school: arithmetic, geography, history, Arabic language, calligraphy, and Christianity. The document specifies the names of books that are permitted to be taught, with the names of their authors and place of publication [9], as follows:

Table 1.

\begin{tabular}{|l|l|l|l|}
\hline Book name & The author & Place of printing & The language of the book \\
\hline Christian education & Turk Mansour & Beirut & Arabic \\
\hline Torah collection & Jesuits & Beirut & Arabic \\
\hline Font Gallery & Jesuits & Beirut & Arabic \\
\hline Golden necklace & Selim Sader & Beirut & Arabic \\
\hline $\begin{array}{l}\text { Teaching geography from } \\
\text { selected writings }\end{array}$ & Unknown & Unknown & Arabic \\
\hline History & Jesuits & Beirut & Arabic \\
\hline
\end{tabular}


The licensing document indicated that officials and teachers need the approval of the General Knowledge Department (Ministry) in the event that new materials are added or changed in the books prescribed for teaching. The license also requires the presence of a representative of the Ministry of Knowledge or Government to oversee, exams and celebrations that take place in the school [9].

Since the Latin community obtained its license to establish a private school in Karak, it sent in the same year Father Paolo Bandoli to the Karak region, where it arrived on Safar 27, 1293 AH / March 23, 1876 A.D., as stated in a letter sent to the Latin Patriarch In Jerusalem, Mansour Brako (Bracco) 1290-1306 AH / 1873-1889 CE, where he describes the community of the community as a nomadic Arab who used to reside in tents at the foot of Mount Shehan overlooking the Wadi Mujib in the Karak region, through the text of the message in which he says: (On March 23, 1876 AD, Karak arrived and analyzed among the nomadic Arabs. On March 25 I opened my school, which includes fifteen boys and nine girls, and the entire number of the Latin community (150) I breathed, and my tent was struck at the foot of Jabal Shehan, which overlooks Wadi Mujib, where Christian tribes struck their bats there.) [9] From the text of this message, it is clear that the school was initially established in the sectarian bats that were dominated by the character of partial displacement during the grazing season. The documents indicate that the construction of the school was completed in $1316 \mathrm{AH} /$ 1898 CE [10], and it is still standing today in its old building in the Christian neighborhood of Karak.

The correspondent of Al-Bashir newspaper issued in Beirut indicated that the school existed and continued to carry out its message to the Latin people when he visited the city of Karak in $1321 \mathrm{AH} /$ 1903 AD [7]. The Latin Patriarchate of Jerusalem obtained a license from the General Ministry's Al-Aref sunglasses to establish a primary school for girls in Karak, and to provide a reference to the presence of the school, as Biddecker mentioned in his tourist guide [11]. There was also a reference to the presence of the school in the newspaper Al-Muqtas, issued in Damascus in 1331 AH / 1913 CE [12].

It can be concluded that the Latin School for Girls came late in terms of establishing that of the male school, and in all cases the documents and information that we have indicate that the Greek Orthodox community was the first in establishing schools for both sexes, and the reason is that the majority of Christians in the Karak region follow the church Orthodox.

\section{4- Missionary Schools in Karak.}

In the field of missionary missionaries, in $1308 \mathrm{AH} /$ 1890AD, the Protestant Church Missionary of the Church dispatched to the Karak missionaries Forder and Lethaby and their wives to carry out missionary activity among the local population, Christians and Muslims [13], and to provide humanitarian assistance in the treatment and treatment of During a medical center established for this purpose, they established an elementary school in the city of Karak in 1309 AH / 1891 AD, and the number of its students in the following year reached (12) students [14]. To increase missionary activity, the Ottoman authorities established a government primary school in Karak in 1311 AH / 1893 CE. [33] And I closed this school Mission, Baedeker has indicated in his guide that there was activity for this missionary association in $1324 \mathrm{AH} / 1906 \mathrm{CE}$, but he did not indicate the existence of a school [15].

\section{Supervising Christian schools and missionary missions in Karak.}

The Public Knowledge System issued in 1286 AH / 1869 AD stipulated that a knowledge council must be formed in every state, district, or judiciary that would supervise education headed by a state employee, in addition to natural members and members elected by the parents and an administrative body from a clerk and treasurer [16], and I have indicated Article one hundred and forty-six of the knowledge system. The tasks that the knowledge councils or people were carrying out by implementing instructions and orders of the Ministry of Education in Istanbul and the Directorate of Knowledge in the State Center of Syria related to education in the district, looking at the conditions of teachers and addressing the shortage in the teaching staff and school supplies, and the governorate Ali Specializations or benefits that are taken from the parents in terms of disbursement and use of them, supervision of the functioning of government schools, researching methods for their development and progress, and submitting an annual report to the Directorate of Knowledge at the Wilaya Center on the conditions of education and problems facing it, and what needs to be done, and the election and replacement of teachers And determine their rewards and permits if necessary, and see the claims related to them [17].

As for the supervision of education in the Karak region, the Syria governorate of $1312 \mathrm{AH} /$ 1894 CE indicates that the first Knowledge Division (Knowledge of Division C) has formed, from the 
legal representative as president and membership of the Director of Edits or Associate, with accounting offices, with the offices of the Sharia court and the first teacher in the elementary school [7].

The following is a list of the heads and members of the Knowledge Division at the Karak Brigade Center who were mentioned in Salamah, Syria:

Table 2.

\begin{tabular}{|c|c|}
\hline Knowledge Division in 1312-1313 AH / 1894-1895 A.D. [38]. & \\
\hline Legitimate Attorney Bahram Wehbe Effendi & President \\
\hline Editor-in-chief Alauddin Effendi & Member \\
\hline With suspicions of Major General Ali Reza Effendi's accountability & Member \\
\hline The first teacher in Karak Primary School & Member \\
\hline Knowledge Division in 1314 AH / 1896AD [39] & \\
\hline Legitimate Attorney Bahram Wehbe Effendi & President \\
\hline Legitimate Attorney Bahram Wehbe Effendi & Member \\
\hline $\begin{array}{l}\text { With suspicions of Major General Ali Reza Effendi's } \\
\text { accountability }\end{array}$ & Member \\
\hline Knowledge Division in 1315 AH / 1897 CE [40] & \\
\hline Sharia MP Muhammad Tahir Effendi & President \\
\hline Editing director Raef Bey & Member \\
\hline With suspicions of Major General Ali Reza Effendi's accountability & Member \\
\hline The Knowledge Division in 1316 AH / 1898 CE [41] & \\
\hline Sharia MP Muhammad Tahir Wehbe Effendi & President \\
\hline Assistant Editor-in-Chief Mohamed Shawkat Bey & Member \\
\hline With suspicions of Major General Ali Reza Effendi's accountability & Member \\
\hline Knowledge Division in $1317 \mathrm{AH} /$ 1899AD [42] & \\
\hline Legitimate MP Muhammad Rahmi Effendi & President \\
\hline Assistant Editor-in-Chief Mohamed Shawkat Bey & Member \\
\hline With suspicions of Major General Ali Bey's accountability & Member \\
\hline With suspicions of Sharia accountability, Muhammad Saeed Effendi & Member \\
\hline Knowledge Division in the year 1318 AH / 1900 A.D. [43] & \\
\hline Legitimate MP Muhammad Rahmi Effendi & President \\
\hline Deputy Director of Editing Muhammad Asad Effendi & Member \\
\hline With suspicions from Major General Muhammed Salim Effendi & Member \\
\hline $\begin{array}{l}\text { With the concerns of the Sharia court, Muhammad Saeed } \\
\text { Effendi }\end{array}$ & Member \\
\hline
\end{tabular}

It should be noted that the state of Syria has mentioned the names of the official members of the employees of the Ottoman Empire in the Knowledge Division, and what are called in that period as natural members, while the members elected from the people were not mentioned, except for what we found in the notes and papers of Metric Zureikat (1292-1368 AH / 1875-1948 AD), who is from the Greek Orthodox community in Karak, where one of the documents that we found in his papers dated March 12, 1327 Mali (44) / 1329 AH / 1911 CE indicates the issuance of a (Burundi) Decree from the administrator and leader of Karak Abd Al-Hamid Bey Ibn Raslan Al-Qalaji (1329-1332 AH / 19111912 AD), which includes certifying the names of the natural members and Elected for the Division of Knowledge of the Karak Brigade Center. The natural members are: Sharia MP Muhammad Shukri Effendi (President), Mufti Raslan bin Hussein bin Mustafa Al-Sharaka who is a resident of the city of Damascus, and a teacher at Karak Al-Rashidiya School Ahmad Effendi, and Jadallah Ahmed as treasurer. As for the elected members mentioned above, they are: On the authority of Christians, Metric Effendi Zureikat, and Boutros Effendi al-Sanaa. As for Muslims, Ford mentioned one member, Husayn al-Tarawneh [18]. The document stated that one of the objectives of this division is to contribute to the advancement of knowledge, checking the conditions of teachers, and supervising the final exams of students [19].

Technical supervision of teaching and implementation of the curricula prescribed in the primary schools in the Karak brigade was among the tasks of the inspectors, where the attic of the 
Ottoman Supreme State for the year 1326 AH / 1908 CE indicates that he is one of the employees of the Ottoman administration in the Karak Brigade Center, the inspector of the primary offices whose name is Ahmad Effendi, and in When the Ottoman calendar for the year 1328 fiscal / $1912 \mathrm{CE}$ referred to the inspector of primary offices, Husayn Effendi [20].

\section{Examinations and holidays in Christian schools.}

It came in Chapter Three of the General Knowledge System issued in 1286 AH / 1869AD, and through its articles from (153-177), established the exam and promotion in primary, rational, preparatory and high schools, and according to the mentioned knowledge system, school examinations in the region were of two types: [21]:

1- Classification Exam: It takes place at the end of each year to move from one class to another within one stage.

2- The desk exam: It takes place at the end of each academic stage, and after success students move from primary education to roshdy, and from roshdy to preparatory school, which was limited to state centers and independent behaviors.

The system has determined the bodies supervising the annual exams, whether inside the stage or the final exams at the end of each stage. Primary school exams are conducted with the knowledge of the school teachers and optional councils in the Kasbah or the Judicial Board of Directors in the district centers.

Article 25 indicates that the period of school suspension is twenty-two days starting from August until the end of three weeks, and Islamic schools are suspended fifteen days from the beginning of the third week of Ramadan to the end of the first week of the month of Shawwal each year.

Schools are also suspended for a week for Eid al-Adha, and schools may not be suspended except on Friday, while non-Muslim schools are suspended on holidays designated for each religion, and all schools are suspended on the day designated for the sultan's seat on the throne of the Sultanate [22].

Article thirty-one of the system of rational offices in the Ottoman Empire issued in the year $1287 \mathrm{AH} / 1870 \mathrm{AD}$ refers to setting the times for the daily official working hours, where schools are opened at eight thirty in the morning, and lessons begin at nine, and the study ends at three in the afternoon, but in winter days it is Opening schools at nine thirty in the morning, and the study begins at ten, and the study ends at four in the evening, and time is allocated from opening the school to starting lessons for students to study [23].

\section{School certificates in Christian schools.}

Article 155 of the General Knowledge System stipulates that students who take the end-ofschool exam will be granted certificates proving their eligibility, and will be able to enroll in the higher stage without applying for the entrance examination to the stage that follows the stage from which it was transferred [24]. There is no information in the public knowledge system indicating the specification of these certificates and the information they contain and the bodies that guarantee their issuance. We have found samples of these certificates belonging to Karak students who have finished their studies in Christian primary schools.

From examining samples of these certificates, we find that they are in the same format, and these models are standardized for all schools throughout the Ottoman Empire.

We have found two testimonies for two Christian students, namely: the student, Selim AlQusous, which includes the certificate of the student's birthplace, which is Karak and its date in 1318 AH / 1900 A.D. In the third line, and below it (primary offices, Namma Si certificate), meaning primary office certificate and written in Diwani script.

On the right of the line that follows, the word (Tam Numro) is written in naskh script, meaning (full mark), and parallel to it on the same line from the left side is (Qranylan numero) with the same line, and the sign means and there is a shaded rectangle under each word.

After that, the names of the subjects are presented in two horizontal lines and under the name of each rectangular material designated for writing down the mark obtained by the student, and the names of the materials are written in the handwriting line, and the materials are: Tajweed of the Holy Qur'an, religious sciences, Ottoman grammar, Turkish readings, Turkish morals, calculation, and civil information, Technical information, history, geography, Arabic, engineering, French, Persian, good calligraphy, drawing.

Because the student with the certificate is Christian, there was no mark in the subjects of the Noble Qur'an and religious sciences, and this note was indicated in the shaded rectangle under the name of the subject. 
In the third line of the testimony, the phrase "be" means the sum of marks, then the word "degree of eligibility, good status and movement" Then the basic information about the student is: name, surname, place of birth, date of birth, and age.

The certificate includes the phrase that states that the student, Salim Al-Qsous, from the last grade students in the primary office in Karak, has performed the exam in the liberated sciences, arts, languages, and fonts, according to which he obtained the acquired information that is required to be collected in primary schools by a group (137 of 140), and an estimate ( At the top), i.e. the first in the class, the above expressions were written in Diwani script, leaving a space to cover the name of the office and the student, the total marks, and the grade the student received.

The certificate bears the signature of the examination committee from the distinguished who are actually supervising the final exams from civil and military officials in addition to the school's teachers. They are: the chairman of the brigade's knowledge committee, the military commander in the Karak brigade, the legal mufti, the head of the Agricultural Bank, and the first teacher in the stage Elementary school, and the second primary school teacher.

Conclusions. There is no doubt that the establishment of schools for Christian denominations and foreign missionaries in the Karak region have contributed to the emergence of political and cultural awareness, which led to the emergence of many Christian learners and intellectuals in the Karak region who had a role in public life in the first half of the twentieth century.

The political awareness has reflected on the behavior and attitudes of members of the Christian communities regarding the issues taking place in the Arab region, especially from political parties and societies.

The state of enlightenment among the members of the Christian communities in Karak led to criticism of the Ottoman policies, arbitrary state actions, and seeking independence and liberation from the Ottoman dependency.

Through a review of the Arab newspapers published at the beginning of the twentieth century, we notice the clear contributions of members of the Christian communities in Karak in writing articles, opinions and political analyzes in newspapers that were published in Syria, Lebanon and Palestine.

The establishment of Christian schools and the spread of education have enabled the children of Christians to take the lead and to precede positive participation in public life, whether at the political, administrative or judicial levels.

This study highlighted the role played by the sectarian and missionary schools in the Karak region, which had a forerunner and leadership in spreading science and culture, as its squares were a meeting place for students of science, both in the city of Karak or the surrounding villages.

\section{REFERENCES}

1. Davison, Roderic. H. The Millets as Agents of Change in the Nineteenth Century Ottoman Empire, New York: Holms Meier Publishers, (1982) p. 320. JB, Hamilton, Wepwen, Harold, Islamic Society and the West, translation: Abd al-Majid Habib al-Qaisi, Dar al-Mada, Damascus, 1997 AD, C 1, Block 2, pp. 247-248.

2. Al-Dustour, 2 CE, translation: Nawfal Neamatullah Nawfal, Literary Press, Beirut, 1883 CE, M1, pp. 2-10. Farid, Muhammad, History of the Attic of the Ottoman Empire, Dar Al-Jeel, Beirut, 1977 AD, pp. 254-260; And see the reforms made by the Ottoman Empire: Juha, Shafiq, "Organizations or Reform Movement in the Ottoman Empire," Research Journal, American University, Beirut, vol. 2, 1965 CE, pp. 107-114.

3. Chaldean, Hanna Saeed, Contemporary Christianity in Jordan and Palestine, Al-Safadi Press, Amman 1993 AD, p. 10; Mears, E. G. and others, Modern Turkey, pp.119-121.

4. Ihsanoglu, Ekmeleddin Ihsan, The Ottoman Empire History and Civilization (Editing), 2 A.D., Center, Research for Islamic History, Art and Culture in Istanbul (Arica), Istanbul, 1999 AD, m2, pp. 543-544.

5. The Latin School License Document in Karak, issued by the General Knowledge Department.

6. Tristram, H.B., The Land of Moab: Travels and Discoveries on the East Side of the Dead Sea and the Jordon, John Murray, London, 1873.

7. Dowling, Theodore E., "Kerak in 1896", Palestine Exploration Fund Quarterly ", PEF, 1896., p330.

8. Khoury, Nicola Khalil, "Memoirs of the Priest of Jerusalem," Future Magazine, Beirut, No. (66), 1982, p. 64.

9. Al-Zureikat, Mitri, unpublished notes and papers, which are kept by his grandson Hassan Yusef al-Zureikat in the city of Karak, paper No. 1 related to his formation and education, p. 1.

10. The Greek Orthodox Church Book in Karak, and it is kept by the Community Prize in the City of Karak, pp. $18,36,38$.

11. The Greek Orthodox Church Book in Karak, and it is kept by the community's Curate in the City of Karak, pp. 2-50. 
12. Hassan Naim, "Imran District of Karak", Al-Muqtabes Newspaper, Damascus, Year (4), Issue (1107), February 4, 1913 AD, pp. 1-2.

13. licensing document for the Latin Church School in Karak, issued by the General Knowledge Department in Istanbul, written in Arabic and found in the Latin Church in Jabal Al-Weibdeh in Amman.

14. Chaldean, Contemporary Christianity, p. 246.

15. Al-Bashir Newspaper, Beirut, Issue (1587), March 30, 1903 CE, p. 3.

16. Baedeker, Karl, Palestine and Syria, Leipzig, Karl Baedeker, 1912. p150.

17. Forder, Alfred, With the Arabs on Tent and Town: The First Missionary Journey into Arabia from the North, 4th Ed., Marshall Brothers, London, 1902, pp60-78.

18. Hornshein, "Aviset Kerak and Petra", 1898, Palestine Exploration Fund Quarterly ", PEF, 1898. pp.98-99

19. Syria Province, 1331-1312 AH / 1893-1894 AD, Syria State Press, 1312 AH / 1893 AD, Batch (26), p. 213.

20. The mandate of the Syrian state in the year 1314 AH / 1896AD, batch (28), Syria State Press, 1314AH / 1896AD, p. 214.

21. Muhammad Siddiq al-Jalili (The Solar Calendar called the Roman Financial Years), Journal of the Iraqi Scientific Academy, M 23, 1393 AH / 1973 AD, pp. 227-239.

22. Zureikat, Metric, Notes and Papers, Document, Date of March 12, 1327 Finance / 1329 AH / 1911 CE.

23. Salamnah, attic of the Ottoman Empire in the year 1328 AH / 1911 AD, batch (67), Ahmad Ihsan Press, Istanbul, 1912 AD, p. 699.

24. Thumrat Al-Funun Newspaper, Beirut, No. 935, December 2, 1899, pp. 3-4. 